\title{
The Cones of the Genus Selaginella.
}

\author{
BY \\ M. G. SYKES, \\ Girton College, Fellowe of Newnham College, Cambridge. \\ AND \\ W. STILES, B.A., \\ Assistant-Lecturer in Botany in the University of Leeds.
}

With Plate XLI.

IN this paper we do not propose to give an exhaustive account of the 1 cones throughout the genus Selaginella, but merely, by describing a few of the more typical species, to draw attention to the great divergence in the form of the sporophylls found in this genus, and in each case to point out the special adaptations for the secure protection of the sporangia. Some of the more complex forms of cone are found to prevail in species which from their radially distributed leaves have been regarded as more primitive in the genus than are the dorsiventral species; this fact is of some interest when considered in relation to various difficult questions concerning the development of the sporangium-bearing organs among the Pteridophyta.

The material of $S$. pumila was obtained by Professor Pearson at Stellenbosch, Cape Colony, and was handed over to us by Professor Seward; S. spinosa and S. helvetica were collected by one of us in Switzerland; we also examined S. Vögelii, S. flabellata, and S. apus, var. elegans, grown in the Cambridge University Botanic Garden, and S. caulescens, of which we used laboratory material. Our thanks are due to Mr. Lynch for kindly sending S. apus, var. elegans, to Kew for identification.

\section{DESCRIPTIVE.}

General. No attempt has hitherto been made to distinguish between the forms of sporophyll characteristic of the various species of Selaginella. Besides the simple sporophylls commonly attributed to the genus, closer examination has now revealed several more complex types. Before describing these it may be well to refer to some characters which are common to all or several of the species.

The cones are usually square, with four rows of sporophylls. The sporangium is generally borne in the axil of the sporophyll. As has been

[Annals of Botany, Vo1. XXIV. No. XCV. July, rgro.] 


\section{Sykes and Stiles.-The Cones of the Genus Selaginella.}

described by Goebel ${ }^{1}$ and Bower, ${ }^{2}$ it always arises from stem tissue, but its first rudiments may develop either in the axil of the sporophyll, or some little way above the axil. In some species, indeed (e. g. S. pumila), even the mature sporangium is never found in the axil of the sporophyll, but is always borne on the stem above the axil.

The line of dehiscence of the sporangium ${ }^{3}$ is perpendicular to its plare of symmetry. It extends for some distance down both sides of the sporangium, and, as the latter is slightly inclined towards the main axis, is cut twice by most of the tangential sections of the cone which pass through it (see Fig. 4, Pl. XLI).

There is a well-developed air cavity in the base of many of the sporophylls, a fact which does not seem to have been recorded before; these air cavities appear to us to be of some interest in that they recall the mucilage cavities of Lycopodium and the parichnos of fossil genera. ${ }^{4}$

The sporophylls of some species are provided with dorsal outgrowths of a more or less pronounced nature. Heironymus ${ }^{5}$ refers briefly to small projections or 'Öhrchen' developed at the base of the sporophyll in S. microcladus, \&c., and Lyon ${ }^{6}$ has figured a dorsal flap in S.rupestris, but even these isolated cases have not been described.

We will now proceed to the description of the various types of sporophyll found in this genus. ${ }^{7}$

Type I. The most interesting and complex type of sporophyll is that found in S.pumila. This species has its foliage leaves radially arranged, and there is therefore a presumption that it approaches the original primitive form of the genus Selaginella. The sporophylls form a compact cone, and are arranged in four rows ; the micro- and megasporangia are somewhat irregularly distributed, and are to a certain extent exposed between the sporophylls (Fig. I, Pl. XLI). The macrosporangia appear regularly to contain four fertile macrospores; the microsporangia are saddle-shaped. The stalk of the sporangium contains a few more or less distinctly elongated cells, whose walls are slightly lignified $;^{8}$ this character, however, is by no

1 Goebel, K., I88I, p. 697 ff.

${ }^{2}$ Bower, F. O., 1894 , p. $5^{22}$ ff.; also Hieronymus, G., in Engler and Prantl, i. 4, p. 655.

3 Goebel, K., I I0I, has described the method of sporangial dehiscence (also Organography, ii, pp. 580-2). See also Mitchell, G., I910, pp. 25-39.

4 See Hill, T. G., I 906 . Hill points out that hitherto nothing comparable with a parichnos had been recorded in Selaginella (p. 270).

${ }^{5}$ Hieronymus, G., p. 654 .

${ }^{6}$ Lyon, F., I901, Fig. 1 24, Pl. IX.

${ }^{7}$ A recent article on the strobilus of Selaginella (Mitchell, G., Ann. of Bot., Jan., I910) has dealt with the questions of the relative distribution of the two kinds of sporangia in the cones of the different species, and has revealed some interesting points in connexion with spore dispersal, \&c. The stelar anatomy has also been dealt with. The present paper was complete before the appearance of Miss Mitchell's article, but we have tried to avoid repetition by cutting out such portions as are now merely confirmatory observations.

${ }^{8}$ Cf. Sykes, M. G., I 908 (2), L. serratum, Fig. 2, P1. III, and L. clavatum, p. 48. 
means so prominent as in some others of the species examined. The sporangium originates (Fig. 2, Pl. XLI) from stem tissue, and though it later becomes associated with a so-called sporophyll, it is never in this species placed accurately in its axil, but is always borne on the stem some little way above the axil (Fig. $3, \mathrm{Pl}$. XLI).

The sporophyll is shortly stalked, and, in addition to the large, upward extending portion of the lamina, there is a downward growing dorsal flap ${ }^{1}$ (Figs. I $b, c, 2,3, \mathrm{Pl}$. XLI). The upper portion folds round, and to some small extent protects the sporangium associated with it. The dorsal flap protects the sporangium which occurs vertically below the sporophyll, ${ }^{1}$ and a groove is also present in the sporophyll stalk into which this sporangium fits ( $g$, Figs. I $c$ and $4, \mathrm{Pl}$. XLI). Fig. 4, Pl. XLI, represents a tangential section through the cone of $S$. pumila, and clearly shows the relative positions of sporangia and sporophylls.

The line of dehiscence of the sporangium is displaced slightly downwards towards the subtending sporophyll; dehiscence thus occurs in the position which in this species best ensures the liberation of the spores opposite the narrow gap between the sporophylls (see Fig. 3, Pl. XLI), at the point most convenient for their dispersal. There is some feeble lignification at the base of the ligule.

It may be of some interest to note that small projections occur on the dorsal surface of the lowest whorl of sporophylls forming the cone, although below these there are of course no sporangia (Figs. I and I $a, \mathrm{Pl}$. XLI). ${ }^{2}$ No such down-growths are developed in connexion with the vegetative leaves.

The stalk of the sporophyll contains no air space, unless we should include in this category a very minute space sometimes found accompanying the stele for a short distance on its lower side ( $a$, Fig. 3 , Pl. XLI).

S. rupestris is the only other form which has yet been described whose sporophylls are similar to those of $S$. pumila. In the cone of this species also, according to Lyon, ${ }^{3}$ a large dorsal flap is present, which protects the sporangium vertically below it. The whole sporophyll here appears to be composed of loosely arranged tissue containing numerous intercellular spaces. ${ }^{4}$

It is interesting to find that these two species are placed near one

1 The arrangement of sporophyllsand sporangia in this cone forcibly recalls Lycopodium cernuum (Sykes, M. G., I908 (2), pp. 48-9; Lang, W. H., I 908); the sporophylls are perhaps even more strictly comparable with those of L. alpinum (Sykes, M. G., I908 (2), p. 48, Fig. $8 a$ and b, Pl. II).

2 In S. Preissiana Goebel found that the lowest sporophylls resembled the foliage leaves instead of being intermediate in character, as in this species (Organography, ii, p. 506).

${ }^{3}$ Lyon, F., I90I, Fig. I24, Pl. IX.

${ }^{4}$ Miss Mitchell (1910, p. 2I) refers to the presence of a 'strongly recurved portion' of the sporophyll 'at the junction of the leaf base and the upturned lamina' in both $S$. rupestris and S. Lyallii; she regards the 'strongly recurved portion' in these two species as a special protective adaptation, but does not add any description. 


\section{Sykes and Stiles. - The Cones of the Genus Selaginella.}

another in the most primitive group of the genus, by both Baker ${ }^{1}$ and Hieronymus, ${ }^{2}$ on the ground that neither species is dorsiventral.

A section of the cone of an unknown species was found in a cabinet of slides at the Cambridge Botany School; unfortunately we have not been able to identify it. The sporophylls of this cone had a remarkably well developed free dorsal flap, relatively larger than that described in S. pumila, and quite solid without any air cavity.

Type 2. The only other species examined which is not dorsiventral is S. spinosa. This form is also placed by Baker in his first group, along with the other non-dorsiventral species, but its many peculiarities make it difficult to regard it as primitive. ${ }^{3}$

Its cone differs from the cones of the other species in being cylindrical; it is very lax and is composed of large simple sporophylls with ciliate margins. ${ }^{4}$

The sporophyll is not folded round the sporangium growing in its axil, and hardly gives it any protection. The sporangium is thus exposed on a sporophyll which is almost flat (Fig. 5, $a$ and $b, \mathrm{Pl}$. XLI), except for a slight depression into which the lower surface of the sporangium fits. There is no definite dorsal flap visible to the naked eye, but minute examination shows a very slight dorsal swelling, most prominent in the median plane of the sporophyll ; the interior of this swelling is occupied by a small air cavity (Fig. $5 d$, Pl. XLI).

The megasporangia each contain four megaspores. The microsporangia are very large, much elongated laterally, and saddle-shaped (Fig. $5 c$, Pl. XLI), recalling the sporangia of some of the Lycopodiums. There are occasionally a few lignified cells in the stalk of the old sporangia, but they are not present in the younger stages.

At the base of the ligule is a cup of tracheides, similar to those recorded by Gibson ${ }^{5}$ in the vegetative leaves of the species he examined. We did not, however, find this cup of tracheides in the sporophylls of most of our species. $^{6}$

Types 3 and 4 (dorsiventral). Among the dorsiventral species a number of forms have been examined. Type 3 is somewhat isolated and is described first: the forms included in Type 4 constitute a series which appears to us to suggest that there has been a progressive change in the form of the sporophyll. From the complex sporophyll with its freely projecting dorsal flap, such as we have described in S. pumila, and such as is probably present in S. Lyallii, ${ }^{7}$ there have been derived sporophylls in which this free

1 Baker, J. G., 1887.

2 Hieronymus, G., pp. 653-664.

3 e. g. the absence of a foot in the embryo; cf. Bruchmann on S. spinosa, 1897, with Pfeffer on S. Martensii, 1870. Gibson appears also to regard the extremely simple stele in $S$. spinosa as peculiar rather than primitive (I894, pp. I 7 I-1 73 ).

4 Glück, H., I895, p. 355. ${ }_{5}^{5}$ Gibson, R. J. H., I896. $\quad{ }^{6}$ See Mitchell, G., I910, p. $3^{2}$.

7 Figured by Hieronymus, G., in Engler and Prantl, i. 4, p. 708, Fig. 408, and referred to by Mitchell, G., I 9 IO, P. 2 I. 
projection is much reduced, but is still to some extent adapted to the protection of the sporangia below it. Finally, there are sporophylls in which this dorsal projection is entirely absent; each sporangium is closely enfolded and protected by the sporophyll which subtends it. It would seem as if this close enfolding of the sporangium by its own sporophyll has gradually taken the place of its protection by outgrowths from other sporophylls.

Type 3. S. helvetica. ${ }^{1}$ The young cone is here composed of compactly arranged sporophylls, but in the older cone the internodes become much elongated, and the sporophylls no longer overlap (Fig, 6, $a$ and $b$, Pl. XLI). Each sporophyll has a prominent dorsal swelling, which is decurrent; in the young cone the two sporangia, which are borne on the alternating sporophylls of the whorl below, are appressed on either side of this swelling (Figs. $6 b$ and $7, \mathrm{Pl}$. XLI). ${ }^{2}$ In the old cone the sporangia are considerably exposed, being only partially protected by the folded edges of the sporophyll in the axil of which they are borne. A large air cavity occupies the decurrent swollen base of the sporophyll; it extends upwards for a short distance into the lamina, being bisected by the entering bundle into two portions; it is crossed by a few trabeculae (Fig. $8, \mathrm{Pl}$. XLI) which increase in number in its upper portion. The surface of the sporophyll is provided with a thin cuticle, which is less strongly developed in the region covering the swollen base.

It is obvious from the above description and figures that in this species the dorsal projection is of no value for the protection of the sporangium except in its youngest stages, and its small size makes it of very little use even in the young cone. It may possibly represent the rudimentary remains of a well-developed dorsal flap, such as is present in S. pumila, and which has here become fused with the stem.

The macrosporangium in $S$. helvetica contains four macrospores. The microsporangium is tangentially somewhat elongated, or saddle-shaped.

An interesting feature is a row of cubical cells with strongly lignified but unpitted walls, which stretch across the stalk of the sporangium from one epidermis to the other, and are already present even at a stage when the sporangium is still quite immature (Figs. 8 and 9, Pl. XLI). In some cases more than one layer of these peculiar cells may be present. The epidermis of the sporangium stalk is also strongly cuticularized. The significance of this feature is at present obscure.

Type $4 a$. In $S$. flabellata and S. caulescens the cone is more compact than in the last species, though the sporangia are still to some extent visible between the sporophylls. Each sporophyll is here more closely

${ }^{1}$ Hieronymus, G., p. 687, Fig. 405 (no dorsal projection is visible in this figure); Luerssen, C., Fig. 225 , p. 864 .

2 This arrangement is essentially similar to that found in the cone of Lycopodium inundatum, though less effective (Sykes, M. G., I909). 
folded round its subtending sporangium (Fig. IO, Pl. XLI) than in any of the species yet described. The base of the sporophyll in S. flabellata is provided with a dorsal ridge which is elongated at right angles to the long axis of the sporophyll, and projects freely downwards (Fig. Io, $b$ and $c$, Pl. XLI). The ridge is strongly curved, and is a little more prominent in the median than in the lateral planes; its ends turn upwards so that in a transverse section of the sporophyll at its base it is cut once, but higher up it is cut twice. It is traversed by an air cavity, and its surface is uncuticularized, while the rest of the sporophyll is covered by a remarkably thick cuticle (Fig. Io $e$, Pl. XLI). The degree of development of the ridge is very variable, and in some cases it is almost entirely absent. The lowest sporophylls have generally a small dorsal projection (Fig. Io $d$, Pl. XLI). ${ }^{1}$

In $S$. caulescens the sporophyll has a much smaller dorsal transverse ridge which does not project freely downwards (Figs. I I $a$ and I I $b$, Pl. XLI). It is curved, and is a little less prominent in the median than in the other planes, so that to the naked eye it appears to constitute two small bulging projections. There is here no definite air cavity.

The microsporangium is round or oval in all the species included in Type 4, and is never saddle-shaped. The line of dehiscence is along a slit placed much as in the more primitive species.

The stalk of the sporangium of $S$. flabellata is composed of several rows of cells with strongly lignified walls (Fig. Io $e$, Pl. XLI); these are well developed even when the sporangium is still quite immature. In $S$. caulescens there is a row of cells with lignified walls which are strictly confined to the base of the sporangium stalk, and are much less prominent than in the other species.

S. flabellata shows a tendency to variation in the number of the megaspores. $^{2}$ In one sporangium two large and two small megaspores occurred; in another there were one large spore, two smaller ones, and two very small ones.

Type 4 b. S. Vögelii, like others of the dorsiventral species of Selaginella, has square cones which are fairly compact; in the young cone of this species the sporangia are entirely concealed.

The cones are very small; each sporophyll is unusually long and so closely folded that in transverse section it appears to be V-shaped; thus it protects efficiently its own subtending sporangium. There is no dorsal flap or ridge adapted for the protection of any other of the sporangia, and no air cavity is present in the sporophyll (Fig. I2, Pl. XLI).

The epidermis of the sporangium stalk is strongly cuticularized, and

${ }^{1}$ See p. $5^{2} 5$, footnote 2. S. Preissiana (Goebel, K., Organography, ii, p. $5^{\circ} 5$ and Fig. 338) probably belongs to Type 4 .

${ }^{2}$ Variation in the number of the megaspores in this and other species is recorded by Mitchell, G., (I910, pp. 24, 25). 
there are a few cells with feebly lignified walls in the stalk of the sporangium, but they are not arranged in rows stretching across it. In S. Vögelii the sporangium has an unusually long stalk.

S. apus, var. elegans, probably also belongs to this group. In the young cone the sporophyll enfolds the sporangium as in other species of this type; the tip of the sporophyll is also turned inwards over the young sporangium in order the better to protect it. The mature microsporangium projects from the enclosing sporophyll, and the association of the mature megasporangium with the sporophyll is not at all close ; indeed, in many cases it is even difficult to be sure which leaf is the one by which the megasporangium was enfolded when young.

As in S. Vögelii, the sporophyll has no dorsal projection at its base. A narrow longitudinal ridge ( $m$, Fig. $\left.{ }_{1} 3 e\right)$, occupied by an air cavity, is however present on the dorsal surface, beginning a little above the base and running, at the back of the midrib, nearly up to the tip of the sporophyll. ${ }^{1}$ This dorsal ridge with its air cavity crossed by trabeculae is very characteristically seen in the V-shaped transverse sections of the microsporophyll.

The distribution of the two kinds of sporangia is a feature of some interest in this species. In the plants grown in the Botanic Garden microsporangia were rare, and at least one plant occurred on which megasporangia only were found, while in another plant there was only one mature microsporangium, but numerous megasporangia ; in all cases the megasporangia were largely in excess. A single megasporangium is generally borne at the base of a terminal cone, which otherwise consists only of a tuft of leaves each associated with an abortive sporangium. In a few cases one or two mature microsporangia occurred in the same tuft as the megasporangium. Abortive sporangia were frequent in all cases, and one cone consisted of aborted sporangia only. ${ }^{2}$ At first it was thought possible that the mega- and microsporangia in this species might ripen at different times on the same plant, but it was found that in a short time the few microsporangia had dehisced; at the end of two months all the megaspores had fallen, and there was no sign of further development of microsporangia. ${ }^{3}$

The number of megaspores in the megasporangium is extremely variable $;^{4}$ in several cases the sporangium contained a single large fertile

1 It appears probable that the small ridge here described is comparable with the median longitudinal wing recorded by Goebel in some of the sporophylls of species whose cones are dorsiventral (Goebel, K., I90I, p. 225 ; and Organography, ii, p. 508, Fig. 340 (S. suberosa)).

2 It is unnecessary to append figures of these abortive microsporangia, as exactly similar ones have been figured by Miss Mitchell in S. Kraussiana (I910, Fig. I 2, Pl. IV).

3 Lyon, F., I901, p. 183 , refers to the limited number of microsporangia in her material of S. apus. It is interesting to find that in $S$. rupestris also, the other form recorded as exhibiting reduction in the number of megaspores in the megasporangium, Hieronymus remarks that he was unable to find any microsporangia; he tentatively suggests that the embryos in this form may be parthenogenetic. It is hoped to investigate the problem later in $S$. apus.

4 Cf. Lyon, F. (I9OI). In S. apus she found four megaspores, but in $S$. rupestris she found a varying number. 


\section{Sykes and Stiles. - The Cones of the Genus Selaginella.}

megaspore, round the base of which were clustered three minute aborted spores (Fig. I3 c, P1. XLI). In other cases the sporangium contained two large and two small spores, or two large and one small spore, \&c.

There are two or three rows of cubical cells with feebly lignified walls in the stalk of the mature sporangium. There is also slight lignification at the base of the ligule in this species.

\section{General REMARKS.}

A. Comparison with Lycopodium and other genera.

(i) The form of the sporophyll. The method of protecting the sporangia by means of sporophylls with both upward and downward extending portions is well known to have been common among the ancient Pteridophyta. The sporophyll both of Lepidostrobus ${ }^{1}$ and of Spencerites ${ }^{2}$ had a more or less well-developed dorsal lobe, and the sterile segments of the sporophylls of Cheirostrobus ${ }^{3}$ had a downward extending portion. Mr. Watson asserts that in Mesostrobus ${ }^{4}$ also the sporophyll had a similar form, but this statement does not appear to be supported by his figures ; consequently it is not possible to make any clear comparison between this and the other genera, and the discussion on pp. 392-3 of his paper is somewhat obscured.

When we find such a series of forms in a single genus as has now been demonstrated in both Lycopodium ${ }^{5}$ and Selaginella, it becomes difficult to place entire confidence in any comparison, based on the forms of the sporophyll, between different genera of widely separated geological ages.

Watson ${ }^{6}$ has grouped together Miadesmia, Bothrodendron, and Selaginella, and it is true that these genera resemble one another to some extent in the position of the attachment of the sporangium. But here it must be remembered that while we have no certain evidence as to where the sporangium originated in the fossil genera, we do know that in Selaginella it arises from stem tissue, and in some species, even in the adult cone, is inserted on the stem above the leaf.

On the other hand, the presence of the dorsal lobe in two probably primitive species of Selaginella suggests a comparison with Lepidostrobus, Spencerites, Lycopodium alpinum, \&c. It is, of course, possible that this method of protecting the sporangia may have been evolved over and over again; still it would appear to be a character at least as valuable for purposes of comparison as is the particular point of attachment of the sporangium.

Pl. XXXVIII.

${ }^{2}$ Berridge, E. M., I 905 ; Watson, D. M.S., I909, Text-fig. 4, p. $3^{8}$ 9.

3 Scott, D. H., I 897 , p. 7 (Diagram),

5 Sykes, M. G., I 908 (2).

4 Watson, D. M.S., I 909 , p. 393.

6 Watson, D. M. S., 1909, p. 391. 
Unfortunately our knowledge of the fossil Selaginellites ${ }^{1}$ is insufficient to make it possible to decide to which of the Selaginella types they most closely approximated. The exact relation of the sporophylls was not apparent in Halle's specimens. Selaginellites Suisse $i^{2}$ is more reminiscent of Selaginella pumila than of the other types, though we do not think much value can be attached to the suggestion. Its multiseriate cones and more numerous megaspores mark this fossil species sharply off from Selaginella.

A more detailed comparison between the series of forms of sporophyll found in the two genera Lycopodium and Selaginella may prove to be of some interest. The remarkable resemblance between the sporophyll of S. pumila and that of Lycopodium cernuum, alpinum, \&c., has been pointed out above. In both cases the dorsal flap of the sporophyll and the groove on the under surface of its stalk ${ }^{3}$ efficiently protect the sporangium vertically below it. The main difference in the sporophylls of these species consists in the nature of the flap, which in L. alpinum and S. pumila is entirely a free down-growth, as it appears to have been in Lepidostrobus, while in L. cernuum it is further modified by adaptations connected with the large mucilage cavity. ${ }^{4}$

One of us ${ }^{5}$ has already expressed the conviction, as one of the results of a comparative study of the sporophylls of Lycopodium, that this dorsal flap is a primitive feature in that genus; its occurrence in two avowedly primitive species of the genus Selaginella appears to us to be suggestive.

$S$. helvetica may be compared with L. inundatum. In both forms the dorsal flap is no longer developed, but a small ridge or swelling is now present which appears to us to represent its reduced remains. S. helvetica seems to stand between $S$.pumila and such forms as $S$. Vögelii much in the same way as does $L$. inundatum between $L$. cernuum and the simpler types of Lycopodium. On the other hand, we know of no forms of sporophyll in the genus Lycopodium which are so clearly intermediate as are the sporophylls of S. flabellata and S. caulescens in the genus Selaginella.

The simpler Lycopodiums differ however from those species of the fourth type of Selaginella in which there is no sign of a dorsal projection, and are more closely comparable with $S$. spinosa, the sporophyll of which appears to be reduced; in them there has been no development of any fresh adaptation for the protection of the sporangium such as has occurred in the dorsiventral Selaginellas.

1 Halle, T. G., I 907 .

2 Zeiller, R., I906.

${ }^{3}$ See Lang, W. H., I 908 , p. 360, Fig. 2. This groove is hardly comparable with the curious furrow on the lower surface of the sporophyll stalk in Bothrodendron (Watson, D. M. S., I908, p. 5I, Text-fig. I).

4 Lang, W. H., I908; Sykes, M. G., I908 (2). It appears as yet uncertain to which of these two forms Spencerites may be most closely compared (Watson, D. M. S., I909), since the evidence as to whether or no there was cohesion between the sporophylls of that genus is not yet conclusive. In either case it does not seem necessary to discuss Mr. Watson's unauthorized extension of Dr. Lang's explanation of Spencerites to Mesostrobus and other genera.

5 Sykes, M. G., I908 (2). 
(ii) The origin and development of the sporangium. The chief contrast between Selaginella and Lycopodium is in the development of the sporangia, which arise from stem tissue in the former, and generally from leaf tissue in the latter. At present we are very much in the dark as to the meaning of this feature. In Miadesmia ${ }^{1}$ the position of the sporangium appears to indicate that it was there developed from leaf tissue. Perhaps in Selaginella the sporangium has never been taken up on to the leaf, or it may be that both here and in Lycopodium Selago the development of that portion of the sporophyll which intervenes between the sporangium and the axis has been dropped out and the sporangium has become reinserted on the stem. ${ }^{2}$ At present such suggestions are mere conjectures.

(iii) The air cavity. The air cavity recorded in the projecting base of the sporophyll of $S$. helvetica, S. flabellata, S. caulescens, \&c., is of some interest; it forcibly recalls the mucilage cavity in the genus Lycopodium, and the parichnos of fossil genera. ${ }^{3}$

(iv) It is perhaps also worth mentioning the lignified cells found in the stalk of the sporangium of S. helvetica and other species. They are, however, hardly comparable with those occurring in the genus Lycopodium, ${ }^{4}$ since their walls, unlike the lignified walls of the cells in the sporangium stalk in species of that genus, have no pits that are visible under the magnifications which we have employed. The lignified walls in both genera stain with iodine green and methyl violet.

(v) The tangential elongation of the microsporangium in S. pumila, S. helvetica, and S. spinosa recalls the saddle-shaped sporangium of so many of the Lycopods, ${ }^{5}$ while the rounded microsporangia of the other forms is more like the sporangium of Bothrodendron, ${ }^{6}$ Miadesmia, ${ }^{7}$ \&c. It appears probable that the shape of the sporangium is a character largely dependent on the relations between the sporophylls and the adaptations for the dispersal of the spores, and is not one which can be relied on for comparative purposes.

B. A tendency towards reduction in the number of megaspores in the sporangium appears to be prevalent in the genus Selaginella, and is found in such widely separated species as $S$. rupestris, S. flabellata, and S. apus. This may possibly represent a survival from Palaeozoic times, when it was very highly expressed in such forms as Miadesmia.

1 Benson, M., I908 (1), p. 420.

2 Sykes, M. G., New Phyt., 1908; and Ann. of Bot., I908.

3 Hill, T. G., I906, p. 270.

5 Sykes, M. G., I908 (2); Benson, M., I908 (2), p. I 45.

7 Benson, M., I908 (2), pp. 420, 421 .

\author{
4 Sykes, M. G., Igo8 (2). \\ 6 Watson, D. M. S., I908.
}




\section{SumMary.}

There have now been described in this genus four main types of sporophylls.

I. In S. pumila, S. rupestris, an unknown species, and probably also S. Lyallii, the sporophyll has a well-developed dorsal flap extending freely downwards, and protecting the young sporangium immediately below it. Two of the species have radially arranged leaves, and are presumably among the more primitive members of the genus.

II. In S. spinosa, the only other radial species examined, there is nothing which can certainly be compared with this free dorsal flap. A slight dorsal swelling is present, occupied by an air cavity; it is possible that this may represent the reduced remains of such a flap. In this species the sporophyll is flat and the sporangium exposed.

III. In S. helvetica, one of the dorsiventral species, there is a welldeveloped dorsal projection which is however not free but decurrent. It is especially prominent in the young cone where the two alternating sporangia of the whorl below are appressed against it. It is suggested that it may be homologized with the free dorsal flap in S. pumila, here fused with the stem.

IV. The species placed in Type 4 form a series, in which the dorsal outgrowth, which originally served to protect the sporangia below, is gradually reduced and lost, while at the same time each sporophyll more and more cornpletely enfolds and protects its own subtending sporangium. In $S$. flabellata there is a transversely elongated dorsal projection the median portion of which extends freely downwards; in S. caulescens the free median portion is lost, and only a small curved ridge is left; in S. Vögelii and S. apus all signs of a dorsal projection at the base of the sporophyll are lost.

The following table is meant to illustrate this comparison of the sporophylls, but is not intended to indicate phylogenetic relationships:-

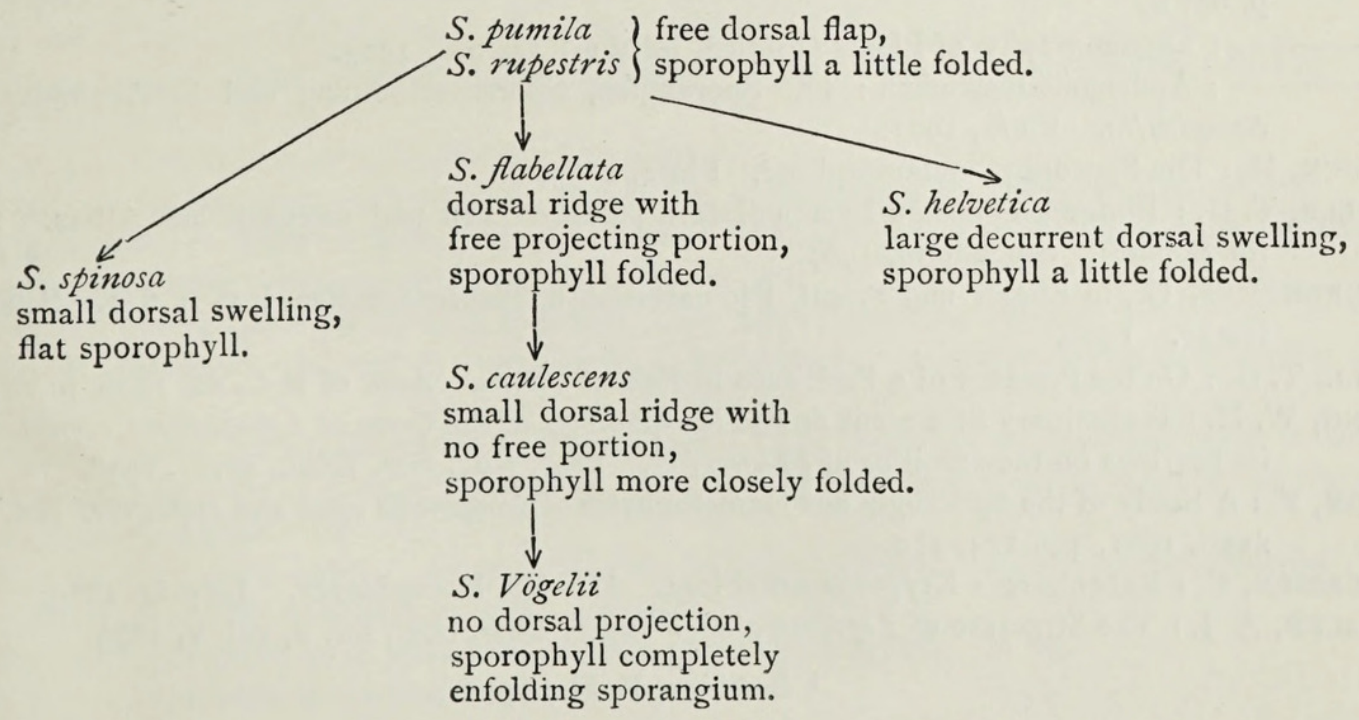




\section{Sykes and Stiles. - The Cones of the Genus Selaginella.}

Finally, it appears to us that we find in this genus a series of forms of sporophyll, the most complex form prevailing in one of the more primitive species. This complex form presents a remarkable resemblance to the form of the sporophyll in Lycopodium alpinum and cernum, and in Spencerites, ${ }^{1}$ and though it would of course be inadvisable to suggest any kind of close relationship between forms otherwise so divergent, we cannot refrain from inferring some significance underlying so close a resemblance.

The development of a complex sporophyll differentiated into dorsal and ventral portions in genera separated in time and in general features so widely as are these three, seems to point to the conclusion that we are here dealing with a very ancient charactcr. We realize, however, that in the light of the instances of parallel development now so frequently revealed, it is not yet possible to regard such a view as definitely proved.

Botany School, Cambridge.

\section{LITERATURE QUOTED.}

BAKER, J. G.: Handbook of the Fern Allies. London, I887.

Benson, M.: (I) Miadesmia membranacea. Phil. Trans., B. 199, 1908.

: (2) The Sporangiophore-a unit of structure in the Pteridophyta. New Phyt., vii, I908, p. I 43 .

Berridge, E. M.: On two New Specimens of Spencerites insignis. Ann. of Bot., xix, 1905, p. 273. Bower, F. O.: Studies on the Morphology of Spore-producing Members. Equisetineae and Lycopodineae. Phil. Trans. B., 1894, p. 522.

Bruchmann, H.: Untersuchungen über Selaginella spinulosa. Gotha, 1897 .

Gibson, R. J. H. : Contributions towards a Knowledge of the Anatomy of the Genus Selaginella: I. The Stem. Ann. of Bot., viii, 1894, p. I33. II. The Ligule. Ann. of Bot., x, 1896, p. 77 .

Goebel, K. : Beiträge zur vergleichenden Entwickelungsgeschichte der Sporangien. Bot. Zeit., I88 I, p. $697 \mathrm{ff}$.

: Organography of Plants (English Edition), Oxford, 1905.

: Archegoniatenstudien: IX. Sporangien, Sporenverbreitung und Blüthenbilidung bei Selaginella. Flora, I9or.

GLüCK, H.: Die Sporophyllmetamorphose. Flora, 1895 .

Halle, T. G. : Einige krantartige Lycopodiaceen paläozoischen und mesozoischen Alters. Arkiv för Botanik. Stockholm, 1907 .

Hieronymus, G., in Engler und Prantl, Die natülichen Pflanzenfamilien, i. 4, p. 621. Selaginellaceae. 1900.

Hill, T. G. : On the Presence of a Parichnos in Recent Plants. Ann. of Bot., xx, 1906, p. 267.

LANG, W. H. : Preliminary Statement on the Morphology of the Cone of Lycopodium cernuum and its bearings on the affinities of Spencerites. Proc. Roy. Soc. Edin., xxviii, I908.

Lyon, F. : A Study of the Sporangia and Gametophytes of Selaginella apus and rupestris. Bot. Gaz., xxxii, 1901, pp. 124, 170.

Luerssen, C. : Rabenhorst's Kryptogamen-Flora. III. Die Farnpflanzen. Leipzig, I889.

Maslen, A. J. : The Structure of Lepidostrobus. Trans. Linn. Soc., ser. 2, vol. v, I899.

1 Berridge, E. M., 1905. 


\section{Sykes and. Stiles.-The Cones of the Genus Selaginella. 535}

Mitchell, G. : Contributions towards a Knowledge of the Anatomy of the Genus Selaginella: V. The Strobilus. Ann. of Bot., xxiv, I910, p. I9.

PfFffer, W.: Die Entwickelung des Keimes der Gattung Selaginella. Hansteins Abhandlungen, I870-I.

Scotr, D. H.: On the Structure and Affinities of Fossil Plants from the Palaeozoic Rocks. On Cheirostrobus. Phil. Trans. B., 189, 1897, p. I.

Sykes, M. G. : The Anatomy and Morphology of Tmesipteris. Ann. of Bot., xxii, I908 (I), p. 63. : Notes on the Morphology of the Sporangium-bearing Organs of the Lycopodiaceae. New Phyt., vii, 1908 (2), p. 4I.

: Note on the Sporophyll of Lycopodium inundatum. New Phyt., viii, I909, p. 143.

Watson, D. M.S. : The Cone of Bothrodendron mundum. Manchester Memoirs, Lit. and Phil. Soc., lii, Part i, I908.

: On Mesostrobus. Ann. of Bot., xxiii, 1909, p. 379.

Williamson, W.: Organization of Fossil Plants of the Coal Measures: Part xix. Phil. Trans. B., 1893 .

Zeiller, R. : Études des Gîtes minéraux de la France. Bassin Houiller et Permien de Blanzy et du Creusot, Fasc. ii. Paris, I906, p. I40.

\section{DESCRIPTION OF FIGURES IN PLATE XLI.}

Illustrating the paper on the cones of Selaginella by Miss Sykes and Mr. Stiles.

Fig. I. Cone of $S$. pumila. $r=$ dorsal flap of sporophyll; $r^{\prime}=$ projection on lowest sporophyll. $\times$ io.

Fig. I $a$. Lowest sporophyll of cone of $S$. pumila. $\quad r=$ dorsal flap. $\quad \times$ I 2.

Fig. I, $b, c$. Sporophylls from middle region of cone of S. pumila. $g=$ groove in sporophyll stalk. $\times 20$.

Fig. 2. Longitudinal section of the apex of a cone of $S$. pumila, showing origin of sporangium $(s p)$ from stem tissue. $l=$ ligule. $\times 54$.

Fig. 3. Radial section of sporophyll of S. pumila. $r=$ dorsal flap; $a=$ small cavity below stele; $d=$ line of dehiscence. $\times 54$.

Fig. 4. Tangential section of cone of $S$. pumila, to show groove in stalk of sporophyll, more pronounced in proximal portion (upper sporophyll), less pronounced in the distal portion (lower sporophyll). The line of dehiscence $(d)$ is cut twice in a tangential section of the sporangium. $g=$ groove in sporophyll stalk into which the sporangium fits. $\times 64$.

Fig. $5, a$ and $b$. Front and side views of sporophyll of $S$. spinosa. $s=$ small dorsal swelling; $h=$ ventral depression. $\times 20$.

Fig. 5 c. Saddle-shaped sporangium of $S$. spinosa.

Fig. $5 d$. Section of sporophyll of $S$. spinosa $. \quad a=$ air cavity in dorsal swelling. $\quad \times 40$.

Fig. $6, a$ and $b$. Parts of young and old cones of $S$. helvetica. $r=$ dorsal projection. $6 b$ shows two young sporangia appressed on either side of $r . \times$ io.

Fig. 6, $c$ and $d$. Sporophylls of $S$. helvetica, back and side views. $\quad \times 20$.

Fig. 7. Transverse sections of young cone of S. helvetica. $s p=$ sporangium; $l=$ ligule; $a=$ air cavity. $\times 54$.

Fig. 8. Radial longitudinal section of sporophyll of $S$. helvetica, showing (a) cavity in dorsal ridge traversed by rows of cells or trabiculae, $(b)$ the row of cells with lignified walls across the base of the sporangium stalk. $\times 54$.

Fig. 9. Ditto from another sporophyll more highly magnified. Note also cuticularization of the epidermis $(e)$ of the sporangium stalk. $\times 170$.

Fig. Io. Sporophyll of S. flabellata, enfolding megasporangium. $\times 10$.

Fig. Io $a$. Contents of macrosporangium. 
536 Sykes and Stiles.-The Cones of the Genus Selaginella.

Fig. 1o, $b$ and $c$. Two sporophylls of $S$. flabellata in side view. $\quad r=$ dorsal projection. $\quad \times 20$.

Fig. Iod. Lowest sporophyll of cone, showing minute dorsal projection.

Fig. roe. Section of sporophyll of S. flabellata, showing dorsal projection containing air cavity, and rows of lignified cells in sporangium stalk.

Fig. I I $a$. Sporophyll of $S$. caulescens, side view. $\quad \times$ io.

Fig. I I $b$. Ditto, back view. $\times 20$.

Fig. I2. Sporophyll of $S$. Vögelii. $\times 10$.

Fig. I $3 a$. End of a fertile branch of $S$. apus, var. elegans. The cone contained only two fertile microsporangia and abortive sporangia. $\times 10$.

Fig. I3 b. Ditto, bearing one megasporangium only and some abortive sporangia. $\times$ Io.

Fig. I $3, c$ and $d$. Spores from megasporangia of $S$. apus, var. elegans.

Fig. I $3 e$. View of sporophyll of ditto from above, showing longitudinal median dorsal ridge $(m) . \times 20$. 
Annals of Botany
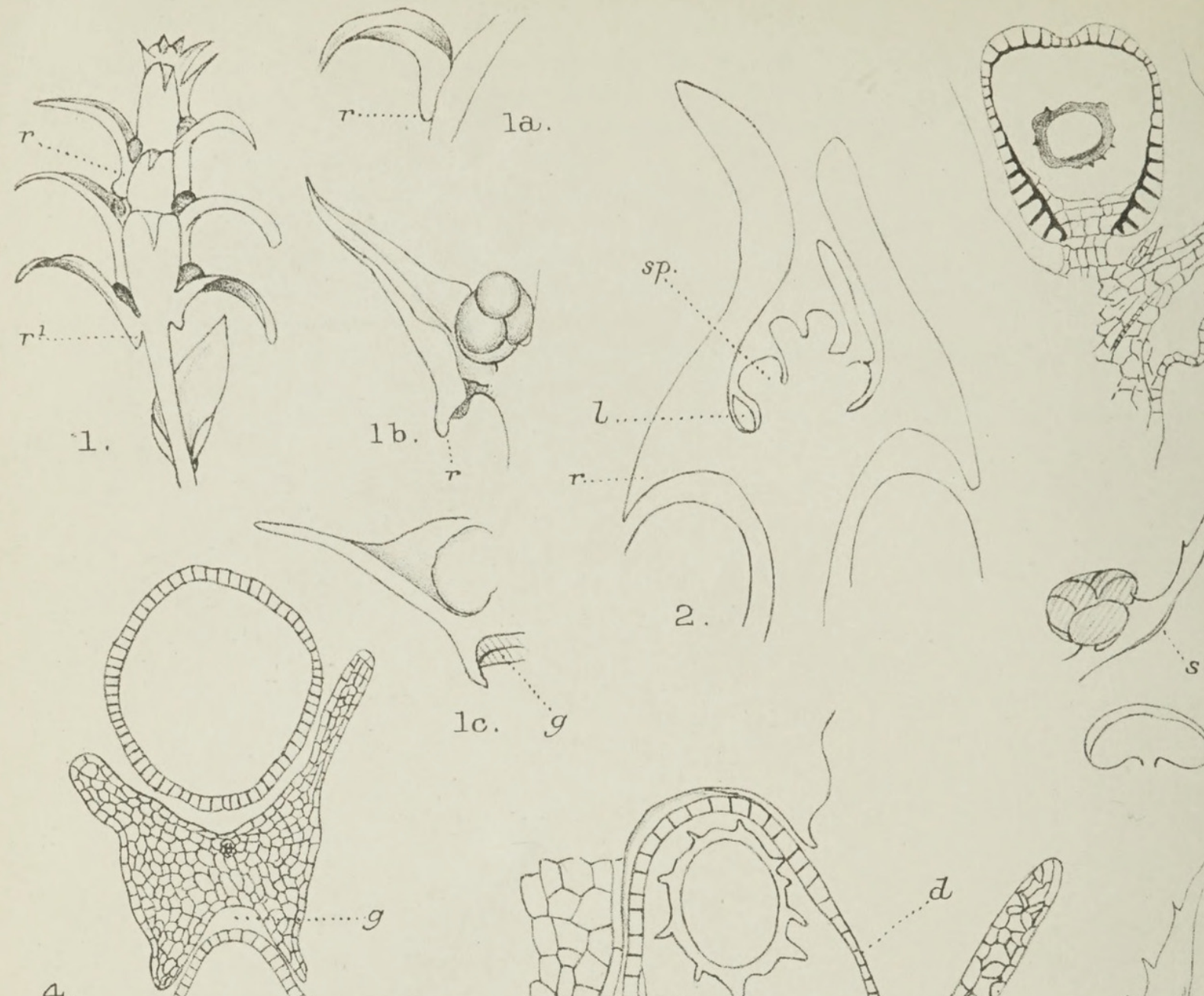

4.
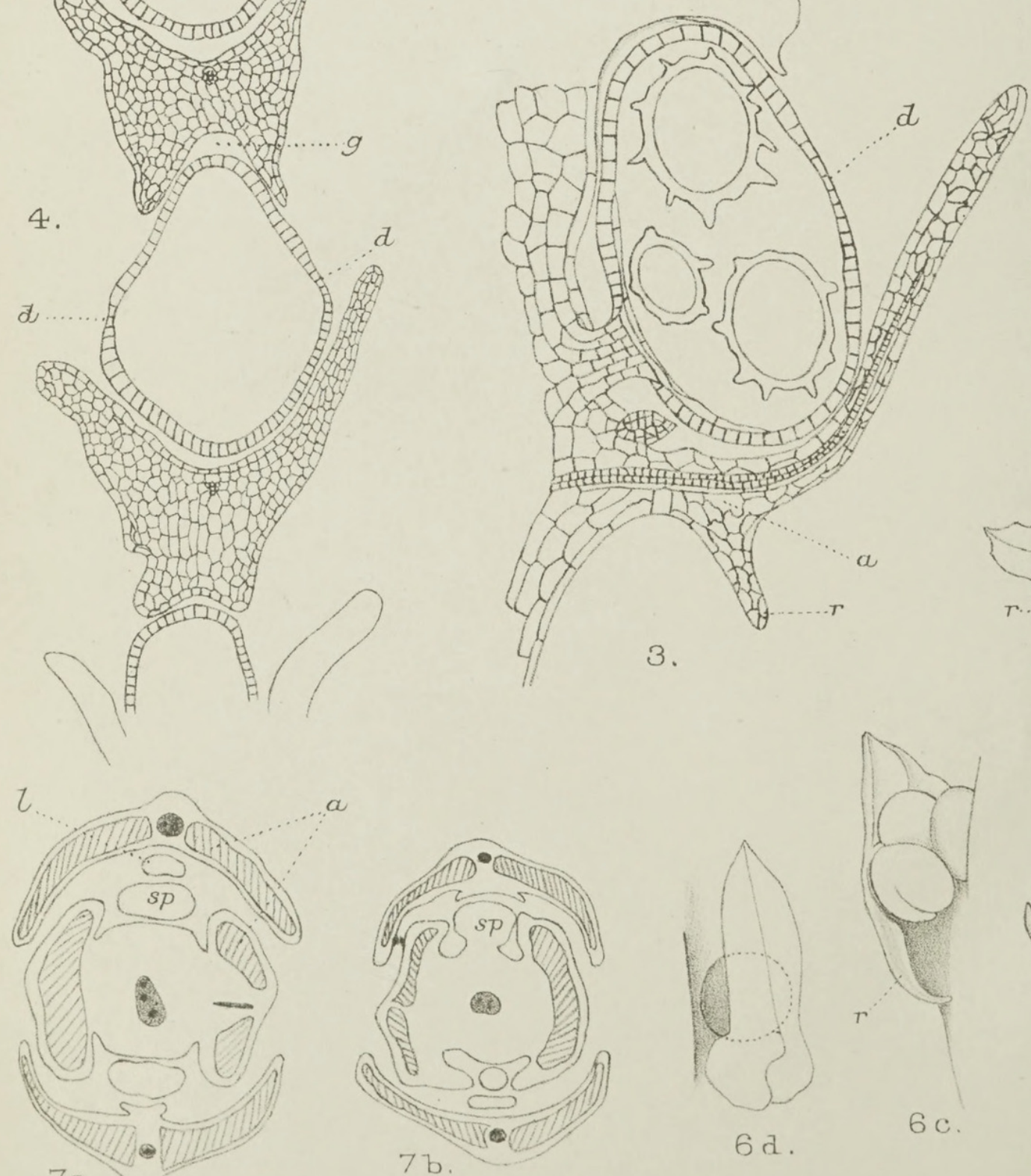

a
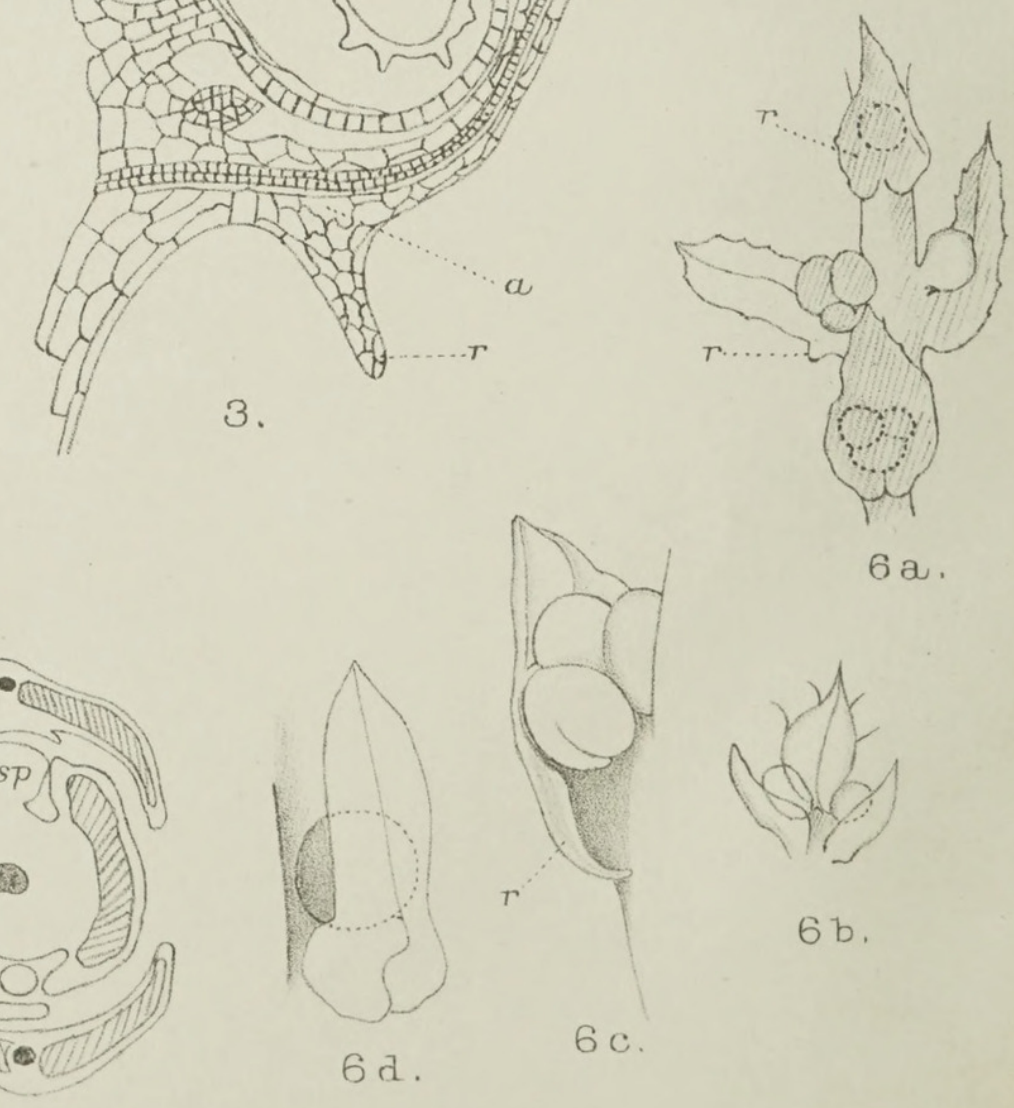

$6 a$
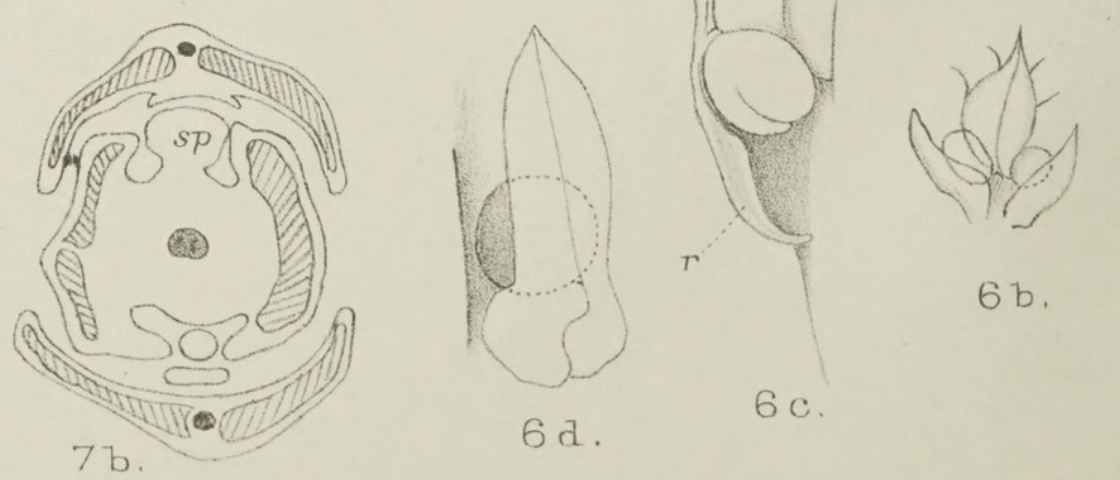

$6 b$. 


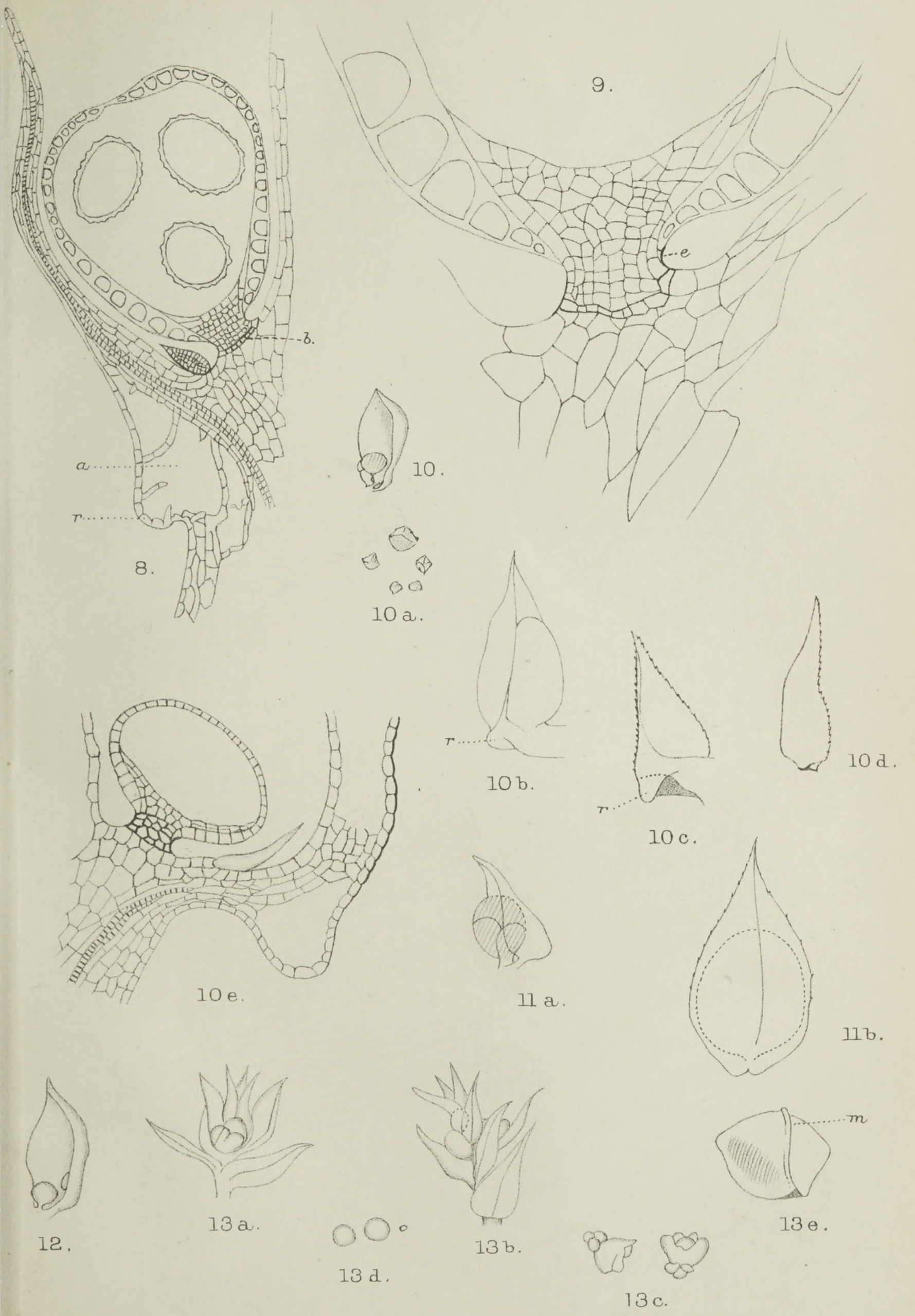




\section{$2 \mathrm{BHL}$ Biodiversity Heritage Library}

Sykes, Mary Gladys and Stiles, Walter. 1910. "The cones of the genus Selaginella." Annals of botany 24, 523-536. https://doi.org/10.1093/oxfordjournals.aob.a089285.

View This Item Online: https://www.biodiversitylibrary.org/item/262605

DOI: https://doi.org/10.1093/oxfordjournals.aob.a089285

Permalink: https://www.biodiversitylibrary.org/partpdf/319793

\section{Holding Institution}

New York Botanical Garden, LuEsther T. Mertz Library

\section{Sponsored by}

BHL-SIL-FEDLINK

\section{Copyright \& Reuse}

Copyright Status: Public domain. The BHL considers that this work is no longer under copyright protection.

This document was created from content at the Biodiversity Heritage Library, the world's largest open access digital library for biodiversity literature and archives. Visit BHL at https://www.biodiversitylibrary.org. 